\title{
In vitro Application of Cadmium within Bone Cement in Osteosarcoma
}

\section{Osteosarkomda Kadmiyumun Kemik Çimentosu İçerisinde In vitro Uygulanabilirliği}

\author{
Nihat Demirhan Demirkiran¹, Pinar Ayse Ercetin², Melek Aydın², Ömer Bekçioğlu², Hasan \\ Havitcioglu', Safiye Aktas ${ }^{2}$ \\ ${ }^{1}$ Kütahya Sağlık Bilimleri Üniversitesi Tıp Fakültesi, Ortopedi Ve Travmatoloji Anabilim Dalı \\ ${ }^{2}$ Dokuz Eylül Üniversitesi, Onkoloji Enstitüsü, Temel Onkoloji Anabilim Dalı \\ ${ }^{3}$ Dokuz Eylül Üniversitesi, Tıp Fakültesi Ortopedi Ve Travmatoloji Anabilim Dalı
}

\section{ÖZET}

GİRIŞ ve AMAÇ: Osteosarkom genelde çocukluk ve genç erişkin yaşlarda görülmekte ve çok agresif seyretmektedir. Tedavide ekstremite koruyucu cerrahi ve kemoterapi yöntemleri ile büyük başarılar sağlanmıştır, ancak mikroskobik düzeyde kalabilen rezidü tümörler rekürrens olasılı̆̆ını arttırmaktadır. Bu çalışmada kadmiyumun kemik çinetosu ile birlikte in vitro uygulanabilirliğini değerlendirilmesi ve cerrahi sonrası lokal uygulanarak rezidü tümör ve rekürrens olasılığını önlemedeki etkinliği için ön bulguların değerlendirilmesi amaçlanmıştır.

YÖNTEM ve GEREÇLER: MG-63 ve K7M2 osteosarkom hücre hatları dört gruba ayrılarak ilk gruba kadmiyumun dondurulmuş kemik çimentosuna emdirilmiş hali; ikinci gruba ise kadmiyumun toz haldeki çimentoya eklendikten sonra karıştırılarak hazırlanmış şekli artan sayılarda hücre hatlarına uygulanmıştır. Sadece kadmiyum çözeltisinin uygulandığı ve kadmiyum eklenmeden standart şekilde hazırlanan kemik çimentosunun uygulandığı hücre hatlarındaki canlılık yüzdeleri ile WST-1 yöntemi kullanılarak karşılaş̧ırılmıştır.

BULGULAR: Kadmiyum eklenip karıştırılarak hazırlanan çimentonun uygulandığı grupta; donmuş çimentoya emdirilerek uygulandığı gruptan daha yükseksitotoksik etki tespit edildi. Tek başına kadmiyum uygulandığında ise 5 ve 10 kat seyreltmeler çalışmadaki en yüksek anti-proliferatif etkiyi gösterdi ( $\% 25$ ve $\% 42$ canlılık).Kemik çimentosunun kadmiyumsuz uygulandığı grupta ise $\% 80$ 'lere ulaşan en yüksek oranda canlılık gözlendi.

TARTIŞMA ve SONUÇ: $\mathrm{Bu}$ çalışma ile kadmiyumun dondurulmuş çimento içerisine emdirilerek ya da çimento hazırlığı sırasında kemik çimentosuna eklenmesi ile uygulanabileceği ve her iki şekilde de Osteosarkom hücreleri üzerine sitotoksik etkiye sahip olduğu gösterilmiştir.

Anahtar Kelimeler: Osteosarkom, Kadmiyum, Kemik çimentosu

ABSTRACT

INTRODUCTION: Osteosarcoma is usually seen in childhood and young adults and presents itself very aggressive. Great treatment success with limb-sparing surgery and chemotherapy are provided, but the residue tumor cells that remains at the microscopic level are increasing the likelihood of tumor recurrence. The aim of this study was to evaluate the in vitro applicability of cadmium with cement and to evaluate the preliminary findings for its effectiveness in preventing the possibility of residual tumor and recurrence by local application after surgery.

METHODS: The MG-63 and K7M2 osteosarcoma cell lines were divided into four groups. The first group included application of bone cement which absorbed cadmium after preparation. The second group of bone cements were prepared with adding cadmium into powdered bone cement was applied to the cell lines in increasing numbers. The percentages of viability in cell lines were evaluated using WST-1 method and compared with bone cement prepared in the standard manner without adding cadmium and application of cadmium solution into cell lines.

RESULTS: Results: In the second group where the cement was prepared by adding cadmium before bone cement mixing; higher cytotoxic effect was detected than the first group which consisted of bone cement which absorbed cadmium after cement preparation. When cadmium solution without bone cement was applied, 5 and 10 -fold dilutions showed the highest anti-proliferative effect in the study ( $25 \%$ and $42 \%$ viability). In the group where bone cement without any cadmium was applied, the highest rate of viability was observed reaching up to $\% 80$. 
DISCUSSION AND CONCLUSION: This study has shown that bone cement either prepared with cadmium or absorbed cadmium after preparation; may be administered as an adjuvant therapy and both have cytotoxic effects upon osteosarcoma

Keywords: Osteosarcoma, Cadmium, Bone Cement.

\section{GíRiș}

Osteosarkom (OS), metastazlar ve multipl myelom hariç tutulduğunda kemikte görülen en sık primer malign tümördür.(1) Y1lda yaklaşık bir milyonda 5 kişide ortaya çıkan osteosarkom, primer malign kemik tümörlerinin \%20'sini oluşturarak ilk sırada yer almaktadır.(2)Çoğu kanserin aksine, osteosarkom, ağırlıklı olarak yaşamın ikinci ve üçüncü dekadında doruğa ulaşan ergenlerin ve gençlerin daha sı etkilendiği bir malignitedir.(3)Sporadik olarak görülen primer OS'un sıklığı 15 yaş civarında büyümenin en hızlı olduğu dönemde pik yapar ve insidans olarak çocukluk çağı kanserleri içerisinde sekizinci sırada yer alır.(4)(5)Bu tümörler tipik olarak hızlı büyüyen uzun kemiklerin metafizinde ortaya çıkan kemik kütleleri olarak saptanır, vakalrın büyük kısmı boy uzamasının en çok olduğu diz çevresi (proksimaltibia veya distalfemurda) bulunur. (6) Geçmişte tutulan uzvun ampute edilmesiyle tedavi edilmeye çalışılan ve özellikle akciğer metastazları sonucu mortalitesi çok yüksek seyreden OS'un sağkalımı \%10'lar civarındayken; cerrahiye kemoterapi protokollerinin eklenmesiyle beş yıllık sağkalım oranları \%70'e ulaşmıştır. (7)(8)

$\mathrm{Bu}$ tümörlerde ekstremite koruyucu cerrahide büyük başarılar sağlanmıştır, ancak mikroskobik düzeyde kalabilen rezidü tümörler rekürrens olasılığını arttırmaktadır. Cerrahi dışında osteosarkom tedavisinde kullanılan yüksek doz metotreksat, sisplatin kemoterapi rejimlerine rağmen de rezidü tümörve metastazlar görülebilmektedir. Bu nedenle yeni tedavi yaklaşımlarına ihtiyaç duyulmaktadır. $\mathrm{Bu}$ çalışmada kadmiyumun kemik çinetosu ile birlikte in vitro uygulanabilirliğini değerlendirilmesi ve yapılması planlanan in vivo çalışmada, cerrahi sonrası lokal uygulanarak rezidü tümör ve rekürrens olasılığ1 önlemesi üzerine etkinliği için ön bulguların değerlendirilmesi amaçlanmıştır.

\section{MATERYAL METOD}

MG-63 ve K7M2 osteosarkom hücre hatları sırasıyla MEM ve DMEM kültür ortamları içerisinde $\quad(\% 10 \quad$ FBS, $\% 1$ penisilinstreptomisin ve $\% 1 \mathrm{~L}$-glutamin ilaveli) $37^{\circ} \mathrm{C}$ 'de \%5 CO2 koşullarda inkübe edildi. (Şekil $1)$.

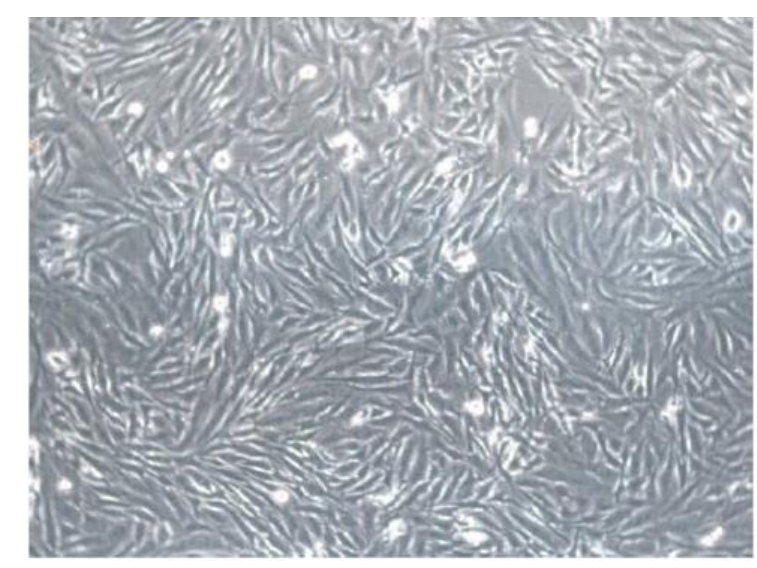

Şekil 1. MG-63 hücrelerinin mikroskobik görünümü

Deney grupları için hedeflenen hücre sayısına ulaşıldıktan sonra $10 \mathrm{mg} / \mathrm{ml}$ dozdaki kadmiyum ve PMMA(polimetilmetakrilat) kemik çimentosu (Biomet Bone Cement, Biomet Orthopedics Warsaw, Indiana, ABD) ile iki farklı in vitro uygulama yapıldı. İlk grupta kadmiyum çözeltisi 5-10-15-20-2550-100-200-300-400-500 kat seyreltilerek dondurulmuş haldeki çimentoya emdirildi ve hücrelerin bulunduğu kuyucuklarda 24 saat bekletildi. (Şekil 2). 


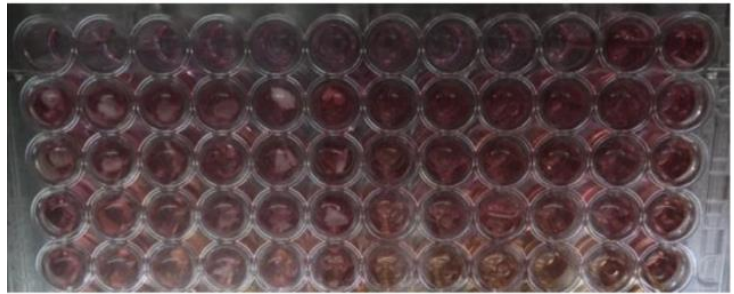

Şekil 2. 96 kuyucuklu hücre hattı tepsisi içerisinde çimentoların uygulanması

Bir diğer uygulama şekli ise 20 kat seyreltilmiş dozdaki kadmiyum çözeltisinin toz haldeki kemik çimentosu polimerine eklendikten sonra siv1 monomeri ile karıştırılarak hazırlanmasını takiben hücre hattını içeren kuyucuklara sayısı artan kemik çinetosu parçaları eklendi ve 24 saat sonra değerlendirildi. Süre sonunda kemik çimentosu kuyucuklardan çıkarılarak WST-1 yöntemi ile hücrelerin canlılıkları değerlendirildi. Diğer taraftan kemik çimentosu sadece kadmiyum çözeltisinin seyreltilmiş dozları da MG-63 hücrelerine uygulanarak 24 saat sonunda hücre canlılığı değerlendirildi. Kadmiyum eklenmeden sadece kemik çimentosunun hücre hatlarına uygulandığ 1 grup ise çalışmanın son grubunu oluşturdu. Her üç gruba da uygulanan çimento şekillerinin por yapıları da mikroskobik düzeyde incelendi. (Şekil 3)
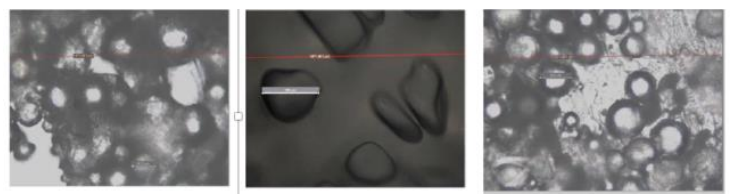

Şekil 3. Kemik çimentolarının por yapılarının mikroskobik düzeyde görünümü (sağda: standart kemik çimentosu, ortada: kadmiyum karıştırılarak hazırlanan çimento, solda: donmuş çimentoya kadmiyumun emdirilmesi sonras1)

\section{BULGULAR}

Her iki osteosarkom hücre hattında da kadmiyumun hücre proliferasyonunu doz bağımlı olarak azalttığ 1 tespit edildi. Tek başına kadmiyum uygulandığında MG-63 hücrelerinde 5 ve 10 kat seyreltmeler en yüksek anti-proliferatif etkiyi gösterdi (\%25 ve $\% 42$ canlılık).(Grafik 1)

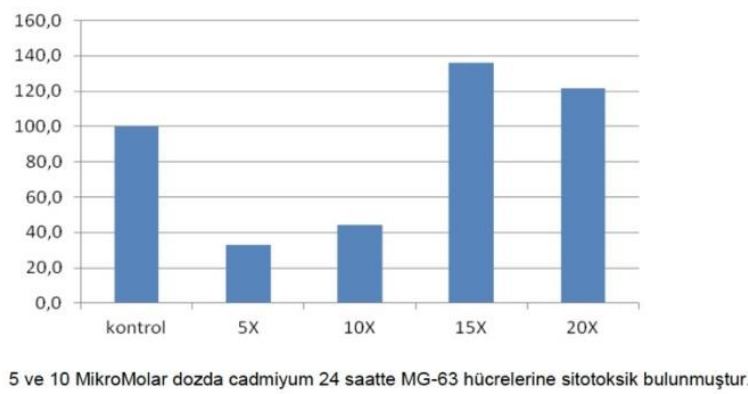

Grafik 1. Kadmiyumun tek başına uygulanması sonrası canlılık değerleri

Kadmiyumun donmuş çimentoya emdirilerek uygulandığ 1 grupta ise daha yüksek seyreltmelerde, tek başına uygulandığ aynı seyreltme koşullarına göre daha etkin anti-proliferatif etkinlik görüldü.(Grafik 2) Kadmiyum eklenip karıştırılarak hazırlanan çimentonun uygulandığı grupta ise; donmuş çimentoya emdirilerek uygulandiğı gruptan daha yüksek sitotoksik etki tespit edildi.(Grafik 3) Kemik çimentosunun kadmiyumsuz uygulandığ 1 grupta ise \%80'lere ulaşan yüksek canlılık gözlendi.

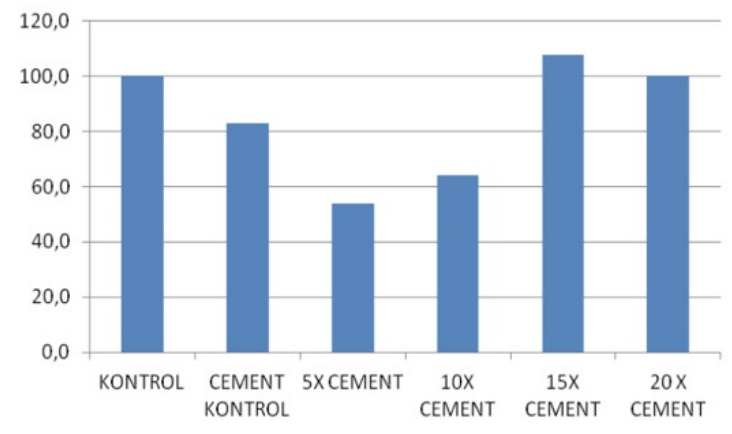

Grafik 2. Donmuş kemik çimentosuna kadmiyum emdirilerek uygulanmas1 sonras1 canl1l1k değerleri 


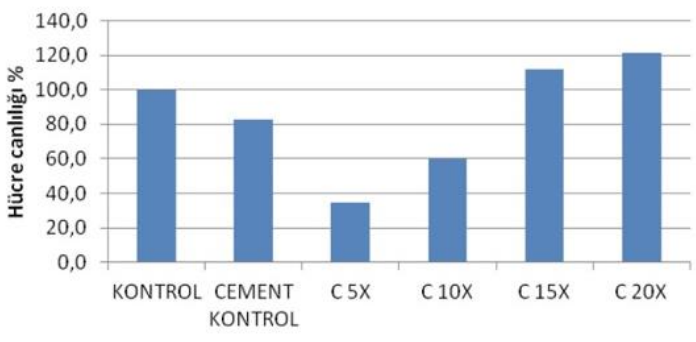

Grafik 3. Kadmiyum eklenip karıştırılarak hazırlanankemik çimentosunun uygulanması sonrası canlılık değerleri

\section{TARTIŞMA ve SONUÇ}

$\mathrm{Bu}$ hastalıklarda tanı için ilk basamak genetik test JAK2 V617F mutasyon analizidir (13). Bu çalışma ile kadmiyumun çimento içerisine emdirilerek ya da çimento hazırlığı sırasında kemik çimentosuna eklenmesi ile uygulanabileceği ve her iki şekilde de osteosarkomda sitotoksik etkiye sebep olduğu gösterilmiştir.

Kadmiyum atom numaras1 48 olan doğal olarak oluşan zehirli bir ağır metaldir. Endüstride ve pil yapımında kullanılan kadmiyum; böbrekler, akciğerler ve iskelet sistemi üzerinde toksik etkilere sahiptir.(9) (10) Kadmiyum toksisitesi kalsiyum metabolizması bozukluklarına, osteomalazi, osteoporoz ve patolojik kırıklara yol açabilir. Kadmiyum zehirlenmesi, kanser indüksiyonu, özellikle akciğer kanseri ile ilişkilidir. Bunun yanında kadmiyuma bağlı prostat, böbrek, karaciğer, pankreas ve mide kanserleri de bildirilmiştir.(11) (12)

Kadmiyum ayrica bir osteotoksin olarak bilinmektedir. (13) Kadmiyum, protein kinaz C (PKC) yolu ile normal Kalsiyum metabolizmasını bozaraknormal kemik gelişimini etkiler. (14) Çeşitli araştırmalar, kadmiyumun sıçanlarda kemik erimesini ve civciv tibialarından kalsiyum salınımını arttırdığını, embriyonik civciv femur kültürlerinde osteoid dokuları azalttığını ortaya koymuştur. (15) (16) (17) Kadmiyumun, özellikle akciğer kanserine yol açarak insanlarda kanserojen etkileri olduğu kanıtlanmış olmasına rağmen; bu in vitro çalışmada osteosarkomdanüksün üstesinden gelmek için osteotoksik etkilerini kemik çimentosuna uygulayarak kullanmayı amaçladık.

PMMA kemik çimentoları literatürde antineoplastik ilaçların lokal adjuvan olarak tümör dokusuna etkilerinin incelendiği çalışmalarda en yaygın kullanılan taşıyıcı malzeme olarak öne çıkmaktadır. Özellikle Osteosarkom gibi malign tümörlerin geniş rezeksiyonu sonrası büyük defektler oluşmakta ve PMMA çimentolar hem oluşan bu defektlerin doldurulmasinda, hem de rekonstruksiyon sirasında uygulanan ortopedik implantların kemiğe tutunmasında yaygın olarak klinik kullanımdadır. $\mathrm{Bu}$ nedenle de invivo ve invitro çalışmaların büyük kısmında antineoplastikajanınların taşıyıcısı olarak PMMA kullanılmıştır. Literatürde PMMA içerisine uygulanan değişikantineoplastik ilaçların kemik çimentosundan salınabildiği ve tümör hücreleri üzerine inhibitör bir etki yaptıkları bildirilmiştir (18). Biz de bu başarıı literatür sonuçları 1şığında, ortopedik cerrahi uygulamalarımızda da sık olarak kullandığımız PMMA kemik çimentosunu çalışmamızda kadmiyumu taşıyıcı araç olarak tercih ettik.

Literatürde PMMA kemik çimentosu içerisine karıştırılarak antineoplastik özellikleri en çok araştırılan ajanların başındametotreksat olduğu görülmektedir (18). Metotraksatın kemik çimentosu içerisinde uygulanması Hernigou ve ark.'nın 1989 tarihli çalışmalarına kadar uzanmaktadır. $\mathrm{Bu}$ öncü çalışmada PMMA'danmetotreksat salınımının olduğu, ekzotermik çimento reaksiyonu sonrası metotreksatın aktif halde olduğu invitro olarak gösterilmiş, ayrıca ratlarda oluşturulan Osteosarkom kitlesinin ortasina metotreksat içeren alçı veya PMMA'dan yapılmış taşıyıcılar uygulanarak tümör canlılığ 
incelenmiştir; ancak ratlarda kitlenin eksizyonu yapılmamıştır (19). Spontan Osteosarkom gelişen köpeklerde ve primer veya metastatik tümörü olan ilk 14 hastaya kemik çimentosu içerisinde metotreksat uygulamalarının sonuçlarını da dahil ettikleri çalışmalarında Hernigou ve ark. 17 köpeğin sekiz ay takip sonrası hayatta kalan 10 tanesinden ikisine ampütasyon uygulamışlar ancak hiçbirinde akciğer metastazı olmadığını bildirmişlerdir. Yine takip ettikleri hastaların tümünde yara drenajında yüksek metotreksat düzeylerine ulaşıldığını ve kanda on güne, idrarda ise üç haftaya kadar metotreksata rastlandığını bildirmişlerdir (19). Benzer şekilde kemik çimentosu içerisine metotreksat uygulayarak SaOS2 ve MG63 osteosarkom hücreleri üzerinde gerçekleştirilen bir başka in vitro çalı̧̧mada ise salınımın ilk gün en yüksek düzeyde olduğu ve azalarak üçüncü haftada bir plato oluşturduğu; buna rağmen tesbit edilebilen canlı tümör hücrelerinin üçüncü günden sonra anlamlı şekilde azaldığı ve bir haftanın sonunda neredeyse hiç rastlanmadığını bildirmişlerdir (20). Metotreksatın kemik çimetosuyla meme kanseri hücrelerine uygulandığı çalışmalarında Maccauro ve ark.ları da ilaç salınımının ilk gün en fazla olduğunu, zamanla azaldığını bildirmişler ayrıca çalışmalarına ekledikleri biyomekanik testler ile eklenmiş olan metotreksatın kemik çimentosunun kompresif direncini azaltmadığını ortaya koymuşlardır (21). Kemik çimentosu içerisinde çalışmaları yapılan bir diğer ajan da sisplatindir. Domuz vertebroplasti modelinde kemik çimentosu içerisinde farklı gruplara metotreksat ve sisplatinin uygulandığ 2017 tarihli bir çalışmada haftalık alınan örneklerde metotreksatın bir hafta, sisplatinin ise üçüncü haftada en yüksek düşeyine ulaştığı ve her iki ilacın da salınımının beş haftaya kadar sürdüğü gösterildi. Bunun yanında miyelosupresyon, hepatotoksisite veya nefrotoksisite bulgularına rastlanmadı. Ancak tümör modeli değil sağliklı domuzlarda yürüttükleri bu çalışmada ilaçların antineoplastik etkinlikleri değil sadece salınım süreleri ve sistemik yan etkileri araştırılabilmiştir (22). Mestiri ve ark. ise çalışmalarında sisplatinininvitro ve tavşan hücrelerinde salınımını incelemişlerdir. Ancak yine tümör modeli içermeyen çalışmada sadece ilacın çimentodan yeterli miktarda salındığı ortaya konmuştur (23). Sisplatinin kemik çimentosu içerisindeki etkilerinin incelendiği ülkemizden yayınlanan bir çalışmada da Özben ve ark. sisplatinin çimentodan salınarak SaOS 2 hücreleri üzerine sitotoksik etki gösterebildiğini ve çimentonun biyomekanik özelliklerini bozmadığını göstermişlerdir (24).

\section{Kadmiyum kronik maruziyette} karsinojenik olarak bilinen bir ajandır. Ancak birçok antikanserojen ajanın toksik ve uzun vadede karsinogenezi tetikleyici olabileceği bilinmektedir. Daha önce kadmiyumla ilgili yapılmış olan deney hayvanı çalışmalarına bakıldığında 1991 yılında Waalkes ve arkadaşlarının Fischer türü sıçanlarda kadmiyumum subkutan uygulamasının kronik karsinojenik ve toksik etkilerini değerlendirdiği görülmektedir (25). Japonya' da kadmiyuma aşırı maruziyet sonrası osteomalazi ve osteoporotik lezyonlara eşlik eden ağır renal yetmezlik ile karakterize "itaiitai hastalığı" tanımlanmıştır (26). Kadmiyumun osteoblastlar da dahil olmak üzere birçok hücrede hem invivo hem invitro olarak apoptozu tetiklediği bilinmektedir. $\mathrm{Hu}$ ve ark. çalışmalarında kısa süreli kadmiyuma maruz birakilan MG-63 osteosarkom hücrelerinde apoptoz oluştuğunu gözlemlemişleridir. $\quad \mathrm{Bu}$ çalışmada kadmiyumum DNA hasarı oluşturarak lokal olarak ameliyat sonrası bölgede kalmış olabilecek tümör hücrelerini öldürücü ya da proliferasyonlarını engelleyici etkisinin olup olmayacağı test edilmiştir.

Çalışmamız kadmiyumun, hem dondurulmuş çimento içerisine emdirilerek hem deçimento hazırlığ çimentosuna eklenmesi sonrası invitro Osteosarkom hücre hattı üzerine sitotoksik 
etkiye sahip olduğunu ortaya koymuştur. $\mathrm{Bu}$ çalışma bulgularına dayanarak kadmiyumun kemik çimentosu içerisinde uygulanmasını in vivoosteosarkomhayvan modelinde cerrahi sonrası lokal gerçekleştirerek rezidü tümör ve rekürrensi önlemedeki etkinliği değerlendirilebilecektir. Ayrıca kadmiyumun canlıdaki sistemik etkisi de tüm dokularda değerlendirilerek ortaya koyulabilecektir. Çalışma sonucunda elde edilen bulgular kemik çimentosu içinde lokal kadmiyum uygulamasının cerrahi sonrası osteosarkomun lokal tedavisine katkıda bulunabileceğini desteklemektedir. Postoperatif ortopedik biyomekanik malzemeler içinde lokal tedavi, osteosarkomda rekürrensi önlemede katk1 tedavi seçeneği olabilir.

\section{Çıkar Çatışması: Yok}

\section{REFERANSLAR}

1. Fox MG, Trotta BM. Osteosarcoma: review of the various types with emphasis on recent advancements in imaging?. Semin Musculoskelet Radiol. 2013; 17(2):123-36.

2. McKenna R, Schwinn C, Soong K, et al. Sarcomas of the osteogenic series (osteosarcoma, chondrosarcoma, parosteal osteogenic sarcoma, and sarcomata arising in abnormal be): an analysis of 552 cases. J Bone Joint Surg Am 1966 ve 48:1.

3. Kansara M, Thomas DM. Molecular pathogenesis of osteosarcoma. DNA and cell biology. 2007 Jan $1 ; 26(1): 1-8$.

4. Ottaviani G, Jaffe $\mathrm{N}$. The epidemiology of osteosarcoma. InPediatric and adolescent osteosarcoma 2009 (pp. 3-13). Springer, Boston, MA.

5. Damron TA, Ward WG, Stewart A. Osteosarcoma, chondrosarcoma, and Ewing's sarcoma: national cancer data base report. Clinical Orthopaedics and Related Research ${ }^{\circledR} .2007$ Jun 1;459:40-7.

6. M. Whyte, Primer on the metabolic bone diseases and disorders of mineral metabolism, in: M.J. Favus, (ed.), American Society for Bone and Mineral Research, Washington, DC (2006), pp. 368-375.

7. Arndt, Carola AS, and William M. Crist. "Common musculoskeletal tumors of childhood and adolescence." New England Journal of Medicine 341.5 (1999): 342-352.

8. Putnam, J. B., Roth, J. A., Wesley, M. N., Johnston, M. R., \& Rosenberg, S. A. (1983). Survival following aggressive resection of pulmonary metastases from osteogenic sarcoma: analysis of prognostic factors. The Annals of thoracic surgery, 36(5), 516-523.

9. IPCS (2005-2007). Cadmium, cadmium chloride, cadmium oxide, cadmium sulphide, cadmium acetate, cadmium sulphate. Geneva, World Health Organization, International Programme on Chemical Safety (International Chemical Safety Cards 0020, 0116, 0117, 0404, 107.

10. IPCS (1992). Cadmium. Geneva, World Health Organization, International Programme on Chemical Safety (Environmental Health Criteria 134 http://www.inchem.org/documents/ehc/ehc/ehc134. $\underline{\mathrm{htm}})$.

11. J.K. McLaughlin, W.J. Blot, S.S. Devesa, J.F. Fraumeni, Renal cancer, in: D. Schottenfeld, J.F. Fraumeni (Eds.), Cancer Epidemiology and Prevention, Oxford University Press, New York, 1996, pp. 1142-1155.

12. K. Nakamura, Y. Yasunaga, D. Ko, L.L. Xu, J.W. Moul, D.M. Peehl, S. Srivastava, J.S. Rhim, Cadmium-induced neoplastic transformation of human prostate epithelial cells, Int. J. Oncol. 20 (2002) 543-547.

13. Angle, C. R., Thomas, D. J., \& Swanson, S. A. (1990). Toxicity of cadmium to rat osteosarcoma cells (ROS 172.8): Protective effect of $1 \alpha, 25$ dihydroxyvitamin D3. Toxicology and applied pharmacology, 103(1), 113-120.

14. Long, G. J. (1997). Cadmium perturbs calcium homeostasis in rat osteosarcoma (ROS 17/2.8) cells ve a possible role for protein kinase C. Toxicology letters, 91(2), 91-97.

15. Bhattacharyya, M. H., Whelton, B. D., Stern, P. H., \& Peterson, D. P. (1988). Cadmium accelerates bone loss in ovariectomized mice and fetal rat limb bones in culture. Proceedings of the National Academy of Sciences, 85(22), 8761-8765.

16. Miyahara, T., Miyakoshi, M., Saito, Y., \& Kozuka, H. (1980). Influence of poisonous metals on bone metabolism: III. The effect of cadmium on bone resorption in tissue culture. Toxicology and applied pharmacology, 55(3), 477-483.

17. Kaji, T., Kawatani, R., Takata, M., Hoshino, T., Miyahara, T., Kozuka, H., \& Koizumi, F. (1988). The effects of cadmium, copper or zinc on formation of embryonic chick bone in tissue culture. Toxicology, 50(3), 303-316.

18. Pountos, Ippokratis, and Peter V. Giannoudis. "Drug-eluting implants for the suppression of metastatic bone disease: current insights." Expert review of medical devices 15.4 (2018): 301-311.

19. Hernigou $P$, Thiery JP, Benoit $J$, Voisin MC, Leroux P, Hagege G, Delepine G, Goutallier D. Methotrexate diffusion from acrylic cement. Local chemotherapy for bone tumours. J Bone Joint Surg Br 1989;71:804-11.

20. Kim HS, Park YB, Oh JH, Yoo KH, Lee SH. The cytotoxic effect of methotrexate loaded bone cement on osteosarcoma cellines. Int Orthop 2001;25:343-8.

21. Maccauro G, Cittadini A, Casarci M, Muratori F, De Angelis D, Piconi C, et al. Methotrexate-added acrylic cement: biological and physical properties. J Mater Sci Mater Med 2007; 18:839-44. 
22. Llombart-Blanco, R., Villas, C., Silva, Á., Aldaz, A., Navarro, I., Forteza, J., ... \&Alfonso, M. (2017). Local and systemic diffusion of antineoplastic drugs following vertebroplasty using acrylic cement mixed with cisplatin or methotrexate: experimental study in pigs. European Spine Journal, 26(12), 3216-3224.

23. Mestiri $M$ BJ, Hernigou $P$, Devissaguet JP, Puisieux F. Cisplatin-loaded poly (methyl methacrylate) implants: a sustained drug delivery system. J Control Release 1995;33:107- 13.

24. Özben, H., Eralp, L., Baysal, G., Cort, A., Sarkalkan, N., \& Özben, T. (2013). Cisplatin loaded PMMA: mechanical properties, surface analysis and effects on Saos-2 cell culture. Acta orthopaedica et traumatologi caturcica, 47(3), 184192.

25. Waalkes MP, Rehm S, Sass B, Konishi N, Ward JM. Chronic carcinogenic and toxic effects of a single subcutaneous dose of cadmium in the male Fischerrat?.Environ Res. 1991;55(1):40-50.

26. Pier SM: The role of heavy metals in human health. Tex Rep Biol Med 975;33:85-106. 